\title{
KOMUNIKACINĖS KOMPETENCIJOS UGDYMAS RENGIANT BŪSIMUOSIUS KŪNO KULTŪROS MOKYTOJUS
}

\author{
Vilija Fominienè \\ Lietuvos kūno kultūros akademija, Kaunas, Lietuva
}

\begin{abstract}
Vilija Fominienė. Lietuvos kūno kultūros akademijos edukologijos krypties doktorantė. Mokslinių tyrimų kryptis — kūno kultūros mokytojų
\end{abstract} komunikacinè kompetencija.

\section{SANTRAUKA}

Straipsnyje nagrinejjama komunikacinès kompetencijos samprata, jos svarba kūno kultūros mokytojo veikloje ir ugdymo galimybès universitetiniu studiju metu. Tyrimo tikslas - nustatyti, ar studiju procese ugdomos büsimuju kūno kultūros mokytoju komunikacinès kompetencijos subkompetencijos, atsižvelgiant i studiju programos turiní. Buvo analizuojama Lietuvos kūno kultūros akademijos studiju programa „Kūno kultūra“: nustatoma, ar studiju dalykai, atsižvelgiant $\dot{i}$ dalyko anotacijas ir programas, suteikia būsimiesiems kūno kultūros mokytojams žiniu, iggūdžiu ir gebejjimu, formuojančiu ju komunikacinę kompetencija. Analizès duomenys parodè, kad ugdant samoningq büsimuju kūno kultūros mokytoju komunikacinę kompetenciją didžiausias dèmesys skiriamas lingvistinei subkompetencijai, visas kitas subkompetencijas ugdant fragmentiškai ir iš dalies. Apibendrinant galima daryti išvada, kad nesukūrus teorinès didaktinès koncepcijos, sistemingai aprašančios ir numatančios komunikacinę kompetenciją lemiančius gebèjimus, kūno kultūros mokytoju rengimo procese komunikacinè kompetencija yra ugdoma nepakankamai.

Raktažodžiai: komunikacija, komunikacinè kompetencija, kūno kultūros mokytoju rengimas.

IVADAS

Z monijos istorijoje susiklosčiusi natūrali žinių mokejjimų bei gyvenimiškos patirties perdavimo forma komunikuojant ir kartu dirbant, todèl ugdymo procesas mokykloje neįmanomas be visas mokytojo ir moksleivio bendrosios veiklos sritis apimančios komunikacijos, išorinès ugdymo proceso dalies (Jakavičius, 1998). Visgi pagrindiniam komunikacinių veiksmų subjektui ugdymo procese esant mokytojui (Bitinas, 2004), ypatinga reikšmè tenka jo komunikacijai. Norint kad specialistas galètų efektyviai dalyvauti veikloje, susijusioje su žmonių tarpusavio ryšiais, ju funkcionavimu, iprasminimu ir tobulinimu, turi būti išugdyta komunikacinė kompetencija. Pastaroji plačiai aptariama tiek užsienio, tiek lietuvių mokslininkų darbuose (Chreptavičienè, 1998 a, b; Millrood, 2001; Almeida, 2002; Grebliauskienè, Večkienė, 2004).

Mokytojo komunikacinè kompetencija, jos būtinumas ir buvimas vienu iš svarbiausių veiksnių, laiduojančiu pedagoginès veiklos sẻkmę, aptariami M. Brooks (1985), D. L. Rogers ir kt. (1990), A. A. Lobanovo (Лобанов, 2002), J. Podgorecki (2005) darbuose. Ši kompetencija, kaip viena 
esminių, išskiriama ir šiuolaikinio kūno kultūros mokytojo profesinèje veikloje (Irvin, 1990; Miškinis, 2000; Beighle, Pangrazi, 2001), todèl komunikacinès kompetencijos ugdymas turètu būti prioritetiniu aukštosios mokyklos, rengiančios kūno kultūros mokytojus, tikslu, kartu ir svarbiu tyrimo objektu.

Komunikacinès kompetencijos ugdymo svarbą ir iškylančias pedagogu rengimo problemas analizuoja R. Malinauskas (1999), D. Aukštikalnytė (2000), Z. Nauckūnaitė (2000), tačiau mažai yra darbų, atskleidžiančiu, kaip ši kompetencija ugdoma rengiant kūno kultūros mokytojus (Nedwidek, Rubinstein, 1970). Nèra darbų, parodančių, kokie studijų dalykai gali būti vertinami kaip paveikūs būsimujų specialistų komunikacinėms žinioms, mokẻjimams ir igūdžiams, todèl šiuo tyrimu norèta išsiaiškinti komunikacinès kompetencijos ugdymo raišką būsimuju kūno kultūros mokytoju rengimo procese.

Tyrimo objektas: komunikacinès kompetencijos ugdymas LKKA studiju programoje „Kūno kultūra“.

Tyrimo tikslas - atskleisti komunikacinès kompetencijos ugdymo raišką rengiant būsimuosius kūno kultūros mokytojus.

Teoriniai kūno kultūros mokytojų komunikacinès kompetencijos ugdymo aspektai.

Komunikacinė kompetencija, būdama neatsiejama šiuolaikinio kūno kultūros mokytojo kompetencijos dalimi, lemia ir visų institucijų, rengiančių šiuos specialistus, uždavinius. Vadinasi, ir Lietuvos aukštoji universitetinė mokykla, rengianti kūno kultūros mokytojus, turi atliepti ši poreikị ir garantuoti efektyvius mokytojo gebejjimo komunikuoti mechanizmus. Vis tik gilinantis i šią temą būtina plačiau paanalizuoti pačios komunikacijos sampratą.

Komunikacija, būdama kelių mokslo dalykų terminu, yra susijusi su įvairiomis tikrovès erdvèmis. Tiriant šiuolaikines komunikacijas, vyrauja du skirtingi požiūriai, kuriuos formuoja proceso ir semiotinès mokyklos. Pirmoji socialinę sąveiką apibrèžia kaip abipusi procesa, kai vienas žmogus sąveikauja su kitais arba paveikia kito elgesị, dvasinę būsena, ir komunikaciją traktuoja kaip pranešimų perdavimą. Antroji socialinę sąveiką supranta kaip tai, kas sukuria individą kaip tam tikros kultūros ar visuomenès nari, ir komunikaciją traktuoja kaip reikšmių kūrimą bei keitimąsi jomis (Fiske, 1998). Nors daugumai mokslininku, tyrinejjančių komunikaciją, proceso mokyklos samprata yra priimtinesnè, J. Fiske (1998) teigia, kad norint priartèti prie esmès reikia išskirti ne kurią nors vieną mokyklą, bet jų suartėjimą.

Išskiriami ir keli komunikacijos lygiai. Siejant ją su žmogiškosios veiklos sritimi, tradiciškai literatūroje pateikiami trys pagrindiniai socialinès komunikacijos lygiai: intrapersonalinis, tarpasmeninis ir masinis. Kasdieneje mokytojo veikloje komunikacija paprastai reiškiasi tarpasmeninių santykių lygmeniu, kai komunikuojama su vienu ar daugiau žmonių. Lietuvos edukologų tokia komunikacija dažniausiai tapatinama su bendravimu, suprantant ją kaip tarpasmeninę arba grupinę žmonių veikla, kurioje keičiamasi patirtimi žodiniais ir nežodiniais signalais (Jovaiša, 1993). Visgi šių terminų tapatumas yra paneigtas N. Večkienès ir kt. (1998) diskusijomis. Jų pagrindu manytume, kad mokytojo komunikacija, pasireiškiančią socialinių santykių sferoje, teisingiausia būtų suprasti kaip sudedamają bendravimo sistemos dali ir komunikacijos plačiają jos prasme tipa, t. y. kaip keitimąsi ugdymo procese informacija (norais, mintimis, jausmais, idejjomis, faktais, vertybėmis) tarp dviejų ir daugiau žmonių.

Komunikacija, kaip ir bet kuri kita veikla, iš asmens reikalauja atitinkamų gebėjimų. Gebejjimas, kuris pagal kvalifikaciją, žinias, mokejjimus ir igūdžius asmeniui leidžia gerai atlikti komunikacinę veiklą i̇vardijamas kaip jo komunikacinè kompetencija (Chreptavičienè, 1998 a). Dažnai komunikacinės kompetencijos terminas vartojamas kalbant apie komunikacinius mokejjimus. Štai B. Grebliauskienè (1999), pristatydama etapinę nerašytinių komunikacinių mokẻjimų ugdymo sistema, ižvelgia tik terminologinius „gebėjimo“, „mokejjimo“, „kompetencijos“ skirtumus, kurių nesureikšmina.

Komunikacinè kompetencija dar skirstoma i sudedamąsias dalis arba subkompetencijas, kurių skaičius ir turinys yra įvairūs. Kalbininkai M. Canale ir M. Swain pateikia teorini komunikacinès kompetencijos modelị, susidedantị iš gramatinès, sociolingvistinès, strateginès ir diskurso kompetencijos dimensijų (Poškienè, 2004). V. Chreptavičienė (1998 a), remdamasi S. Moirand komunikacinès kompetencijos modeliu, komunikacinę kompetenciją skaido ị lingvistini, diskurso, referatyvinị ir socialinį-kultūrinį komponentus. Z. Nauckūnaitè (2000) skiria lingvistinę, diskursinę, sociolingvistinę, sociokultūrinę ir referatyvinę komunikacines subkompetencijas. I. Cecevičiūtès (2003) manymu, labiausiai priartėjęs prie socia- 
linių mokslų erdvėje susiformavusios holistinės kompetencijos koncepcijos, akcentuojančios gebejjimą žinias ir igūdžius perkelti į naujas situacijas ir tuo pačiu leidžiant žmogui veikti įvairios veiklos srityse, laikytinas J. A. van Ek ir J. Sheils (1995) pateiktas komunikacinès kompetencijos modelis. Jie komunikacinę kompetenciją skaido i šešias sudedamąsias, glaudžiai susijusias dalis: lingvistinę, sociolingvistinę, diskurso, strateginę, sociokultūrinę, socialinę subkompetencijas ir nurodo, kad ugdant komunikacinius gebejjimus turi būti atsižvelgiama į visas jas. Teigiama, kad lingvistinès subkompetencijos ugdymas gilina žodyno žinias, ivvaldomi kalbos struktūros dėsningumai (gramatika). Ugdant sociolingvistinę kompetencija mokoma(si) vartoti ir interpretuoti kalbos formas pagal bendravimo situaciją: situacijos turinys (kas su kuo, apie ka, kur ir kokiu tikslu komunikuoja) lemia kalbos formų parinkimą. Ugdant(is) diskurso subkompetenciją, mokoma(si) suprasti bei formuoti rišlius ir aiškius pasakymus, strateginę - siekiama, kad studentas igustų verbalines priemones paremti neverbalinėmis ir taip išmoktu kompensuoti žinių trūkumą. Puoselèjant socialinę kompetenciją, ugdomas pasitikejjimas savimi ir noras bendrauti, keistis informacija su kitais, mokejjimas tinkamai elgtis ịvairiomis socialinėmis situacijomis, o sociolkultūrinès subkompetencijos ugdymas apima žinias, susijusias su sociokultūriniu kontekstu, kuriame ta kalba vartojama.

Komunikacinè kompetencija tikrają savo kokybę igyja tik aktyviai veikiant, t. y. efektyviai naudojantis mokejjimais komunikuoti. O šiuos mokejjimus pirmiausia lemia konkreti mokytojo dalykiné veikla ugdymo procese. Kadangi tai dinamiška, emocinga, dažnai susijusi su konfliktinių situacijų sprendimu ir su įvairiomis aplinkomis (klase, sporto sasle, stadionu ir pan.) veikla, M. Irvin (1990) nurodo, kad komunikuodamas kūno kultūros mokytojas turi gebẻti naudoti aiškią ir suprantamą rašytinę bei sakytinę kalbinę raišką; aiškinant, analizuojant, ittikinejjant ar vertinant gebeti pritaikyti komunikacijos turini ir stilių; priklausomai nuo situacijos ir klausytojų vartoti tinkamą kalbos stilių bei žodyną; mintis mokèti reikšti ivvairiomis formomis - rašytine ar sakytine kalba, simboliais, neverbaline kalba. Vadinasi, kūno kultūros mokytojų rengimo procese labai svarbu būsimam specialistui sudaryti tokias mokymosi ir studijų sąlygas, kad igytos žinios, mokejjimai bei igūdžiai leistu jam sėkmingai ir efektyviai komunikuoti jo profesinèje veikloje, o ateityje padètų igyti naujų žinių, reikalingų tobulinant esamus mokèjimus. Taigi būtina ugdyti gebèjimą naudotis tiek lingvistiniais, tiek nelingvistiniais komponentais. Sudijų procese dèmesys turi būti skiriamas visoms subkompetencijoms, nes tik ju visuma ir glaudus ryšys leis mokytojui efektyviai atlikti komunikacinę fizinio ugdymo veiklą.

\section{TYRIMO METODIKA}

Komunikacinès kompetencijos ugdymo raiškai ivvertinti naudojome dokumentų turinio analizès metodą (Kardelis, 2002). Šios analizès metu rèmèmès nuostata, kad kūno kultūros mokytojas, baigęs studijas aukštojoje mokykloje ir igijęs profesinę kvalifikacija, privalo turèti sąmoningą komunikacinę kompetencija, susidedančią iš lingvistinès, sociolingvistinès, diskurso, strateginès, sociokultūrinès ir socialinès subkompetencijų. Tuo tikslu buvo atlikta kokybinè oficialiu verbalinių dokumentų — būsimujuu kūno kultūros mokytoju studiju programos turinio analizè. Jos metu nagrinejjamos atskirų studijų programos dalykų anotacijos ir programos nustatant, ar dalyko tikslas yra suteikti studentams žinių, mokejjimų ir igūdžiu, lemiančiu jo komunikacinę kompetenciją. Jei dalyko tikslas nėra nukreiptas ị komunikacinès kompetencijos ugdyma, analizavome, ar atskiros studijų dalyko temos neturi įtakos atskirų komunikacinès kompetencijos komponentu formavimui.

Nustačius studijų dalykus, tiesiogiai ar iš dalies ugdančius komunikacinę kompetenciją buvo atlikta duomenų statistinè analizè, atskleidusi visos studijų programos komunikacinės kompetencijos ugdymo apimti.

Analizavome LKKA studijų programą „Kūno kultūra“ (2004), nes ši aukštoji mokykla parengia 80\% Lietuvos sporto pedagogų ir baigus šią programą yra suteikiama profesinè kvalifikacija bei akademinis (bakalauro) laipsnis.

\section{REZULTATAI}

Atliktos kokybinės studijų programos turinio analizès rezultatai rodo, kad LKKA studiju programoje tik vieną „Kalbos kultūros ir specialybės kalbos“ privalomaji studijų dalyką galime išskirti kaip tiesiogiai ugdantị būsimuju kūno kultūros mokytojų komunikacinę kompetenciją. Dalyko anotacijoje nurodoma, kad šio kurso tikslas - lavinti studentų valstybinę kalbą, ugdyti kalbos igūdžius, reikalingus būsimai specialybės veiklai. 
Lentelè. Studijų dalykų temų, plètojančių būsimojo kūno kultūros mokytojo komunikacinę kompetenciją, turinys

\begin{tabular}{|c|c|c|c|}
\hline Temos pavadinimas & $\begin{array}{l}\text { Teorija, } \\
\text { h sk. }\end{array}$ & $\begin{array}{l}\text { Praktika, } \\
\text { h sk. }\end{array}$ & Plėtojama subkompetencija \\
\hline $\begin{array}{l}\text { Valstybės kalba. Specialybės kalbos } \\
\text { dalykas. Kalbos normų pažeidimai, jų } \\
\text { vertinimas }\end{array}$ & & 2 & Lingvistinè \\
\hline Tarties ir kirčiavimo klaidos & & 4 & Lingvistinè \\
\hline Leksikologija. Oratoriaus kalbos kultūra & & 8 & Lingvistinè \\
\hline Daryba & & 4 & Lingvistinè \\
\hline Morfologija & & 4 & Lingvistinè \\
\hline $\begin{array}{l}\text { Sintaksinė terminų daryba (linksniai ir } \\
\text { prielinksniai }\end{array}$ & & 4 & Lingvistinè \\
\hline $\begin{array}{l}\text { Profesinio teksto struktūra ir stilius. } \\
\text { Specialieji raštai }\end{array}$ & & 4 & Lingvistinè \\
\hline Mokslinio teksto taisymas & & 2 & Lingvistinè \\
\hline $\begin{array}{l}\text { Sutrikusio intelekto žmonių, kurčiujų ir } \\
\text { prigirdinčiujų komunikacija ir } \\
\text { tarpasmeniniai santykiai }\end{array}$ & 2 & & $\begin{array}{l}\text { Sociolingvistinè, diskurso, } \\
\text { strateginė }\end{array}$ \\
\hline $\begin{array}{l}\text { „Aklojo“ judrumas ir komunikacija: } \\
\text { asmeninė patirtis žaidimo situacijomis }\end{array}$ & & 2 & $\begin{array}{l}\text { Sociolingvistinè, diskurso, } \\
\text { strateginè }\end{array}$ \\
\hline $\begin{array}{l}\text { Bendravimas gestais. Daktilinė kalba. } \\
\text { Skaitymas iš lūpu }\end{array}$ & & 2 & Sociolingvistinè, diskurso \\
\hline Veikla ir bendravimas & 2 & & Socialinè, sociokultūrinè \\
\hline $\begin{array}{l}\text { Sporto pedagogo bendravimo su } \\
\text { ugdytiniais ypatumai }\end{array}$ & 2 & & Socialinè \\
\hline $\begin{array}{l}\text { Trenerio bendravimo ir bendradarbiavimo } \\
\text { su komanda aspektai }\end{array}$ & 2 & & Socialinè \\
\hline Sporto pedagogo bendravimo priemonès & & 2 & Socialinè, strateginè \\
\hline Iš viso & 8 & 38 & \\
\hline
\end{tabular}

Išskiriami ir penki uždaviniai: suvokti pagrindines bendrinès lietuvių kalbos normas; gebėti naudotis „Kalbos praktikos patarimais“ ir kita kalbine literatūra; lavinti savo kalbos jausmą ir išmokti taisyklingai lietuviškai kalbèti; susidaryti studijuojamos specialybės kalbos pagrindus; tobulinti profesinę kalbą.

Prie dalyku̧, iš dalies lemiančių būsimujų kūno kultūros mokytoju komunikacinę kompetenciją, buvo priskirtas privalomasis studiju dalykas „Specialioji pedagogika ir psichologija“, kurio anotacijoje teigiama, kad kurso metu bus „ugdomi bendravimo su neigaliaisias igūdžiai“. Privalomieji studijų dalykai „Bendroji ir sporto pedagogika“, „Bendroji ir sporto psichologija“ taip pat iš dalies ugdo komunikacinę kompetenciją, kadangi atskiros kursų temos atitinkamai yra skirtos sporto pedagogo bendravimo su ugdytiniais ypatumams, trenerio bendravimo ir bendradarbiavimo su komanda aspektams, sporto pedagogo bendravimo priemonėms, veiklai ir bendravimui.
Atskirų studijų dalykų temų analizè (lent.) atskleide, kurios komunikacinès kompetencijos subkompetencijos yra plètojamos nagrinejjant atskiras temas.

Norint atskleisti komunikacinès kompetencijos ugdymo apimti, buvo taikomas aprašomosios statistikos metodas ir apskaičiuota, kad komunikacinei kompetencijai ugdyti studiju programoje yra skiriama 1,64\% viso studijoms skirto laiko valandomis, iš ju pratyboms skiriama 1,35\%, teoriniams užsièmimams $-0,29 \%$ viso studijų laiko.

Nustačius valandų skaičių, skiriamą komunikacinei kompetencijai ugdyti, apskaičiavome, kad 17,39\% laiko skirta paskaitoms, o likęs laikas (82,61\%) - pratyboms.

$76,2 \%$ viso komunikacinès kompetencijos ugdymui skirto laiko tenka lingvistinei subkompetencijai, kita laiko dalis - sociolingvistinèms, socialinėms, strateginėms, diskurso ir sociokultūrinès subkompetencijoms plètoti. 


\section{REZULTATŲ APTARIMAS}

Studiju programos ir dalykų turinio analizè atskleidè, kad komunikacinès kompetencijos ugdymas LKKA studijų programoje „Kūno kultūra“ daugiausia apsiriboja lingvistiniu lygmeniu, nes didžiają dali viso komunikacinei kompetencijai plètoti skiriamo laiko užima taisyklingos kalbos mokèjimu (leksikos, gramatikos, tarties, rašybos, skyrybos) ugdymas. Nors lingvistinè subkompetencija yra esminė komunikacinès kompetencijos dalis, jos pamatas, remiantis „Lietuviu kalbos ugdymo bendrojo lavinimo mokyklos strategija 2004-2009 m.“ (2003), teigiančia, kad baigdamas vidurinę mokyklą mokinys, kurdamas ivvairius tekstus, turi puikiai išmanyti kalbos sistema, galima būtų manyti, kad studentai, pradèję studijuoti pasirinktą studijų programą jau turètų būti susiformavę ivvairius mokèjimus, lemiančius jų lingvistinę subkompetenciją. Visgi taip nèra, nes kitose Lietuvos aukštosiose mokyklose, rengiančiose kūno kultūros mokytojus, bakalauro studijų programose tarp privalomujų yra šie dalykai „Kalbos kultūra ir specialybès kalba“ (VPU), „Specialybès kalbos kultūra“ (ŠU) ir „Kalbos kultūra“ - (KU). O ir kalbos, kaip kokybiškos komunikacijos kodo, tyrimas atskleidè, kad būsimieji kūno kultūros ir sporto pedagogai kalboje dažnai vartoja neteiktinus vertinius, veiksmažodines formas ir daro kitas didžiąsias kalbos kultūros klaidas, kurias ištaisyti turèjo būti išmokę bendrojo lavinimo mokykloje (Kardelienè ir kt., 2004). Taigi lingvistinès subkompetencijos, kaip esminès komunikacinès kompetencijos dalies, ugdymas aukštojoje mokykloje kol kas yra būtinas. Visgi jis nelemia sąmoningos mokytojo komunikacinès kompetencijos, kuomet žinoma, ką daryti, kad komunikacija vyktų sklandžiai ir mokytojas mokètų taikyti savo žinias. Vadinasi, reikia ugdyti ir kitas subkompetencijas. Deja, visos kitos komunikacinės kompetencijos subkompetencijos ugdomos fragmentiškai ir iš dalies. Studiju programoje nei tarp privalomuju, nei tarp pasirenkamujų nėra tokių dalykų kaip „Bendravimo etika“ ar „Pedagoginè etika“, kurie tiesiogiai ugdytu gebejjimą pagal bendravimo situaciją tinkamai vartoti bei interpretuoti verbalines ir neverbalines raiškos priemones. O jos nurodomos kaip vienos iš pagrindiniu pedagoginio bendravimo procese (Лобанов, 2002). Pasigendama „Bendravimo psichologijos“ ir „Pedagoginès psichologijos“ dalykų, kurių metu būtų aptariami pasakymo motyvai, minties formavimo procesai, grižtamasis ryšys, pasakymo prognozavimas. Nèra galimybės pasirinkti „Komunikacinès veiklos pagrindu“, „Iškalbos meno“, „Dalykinio bendravimo“ dalykų, kurie studentams teiktų žinių apie kalbos modelius ir mokejimą jais naudotis.

Štai JAV būsimujų kūno kultūros mokytojų komunikacinès kompetencijos ugdymu susidomèta praeito amžiaus septintajame dešimtmetyje. Jau 1969 m. N. Cousins pažymèjo, kad viena iš silpnųjų ugdymo aukštojoje mokykloje vietu — tai, kad neskiriama reikiamo dèmesio komunikacinei kompetencijai plètoti, nors pripažistama, jog ji lemia mokytojo bendravimą su mokiniais (Nedwidek, Rubinstein, 1970). Todèl dabartinėse šios šalies kūno kultūros mokytojų rengimo programose kaip privalomi dalykai yra „Kalbos pagrindai“ (Fundamentals of Speech), „Kalba ir raštingumas“ (Language and Literacy), tarp pasirenkamuju dalyku „Komunikacijos teorija“ (Communication Theory), „Retorika ir jos analize“ (Rhetoric and Rhetorical Criticism), „Vadovavimo komunikacija“ (Leadership communication) ir daugelis kitu dalykų. Šių dalykų įtraukimas ị studijų programas yra gana logiškas žingsnis, nes šiuolaikiniame pasaulyje, taip pat ir mokytojų profesinejje veikloje, komunikaciniai asmens gebèjimai laikomi vienais iš esminių. Deja, anot B. Grebliauskienès (1998), Rytų Europos aukštosiose mokyklose komunikacinių mokejjimų ugdymas neturi gilių tradicijų, o abiturientai, tapę universiteto ugdytiniais, yra igije tik atsitiktinių šios srities žinių ir nėra pasirengę vertinti savo komunikacinės veiklos.

Nors verbalinių dokumentų analizè neatskleidè daugiau studijų dalykų, ugdančių komunikacinius studentų mokejjimus, tikètina, kad ir kitų studijų programos dalykų atskiros temos plètoja komunikacinę kompetencija, kadangi studiju programos pagrindime teigiama, kad studijuojantieji pagal šią programą igyja žodinio ir rašytinio bendravimo igūdžius, kuriuos galima įvardyti kaip asmens komunikacinę kompetenciją. Visgi jei nėra sudarytos komunikaciniu mokejjimų ugdymo programos, kuri skatintų atitinkamų komunikacinių mokejjimų ugdymo integravimą $\mathfrak{i}$ ivairius studijų programos kursus, būsimujuc kūno kultūros mokytoju komunikacinė kompetencija ugdoma stichiškai ir priklauso nuo atskirų dėstytojų. Tą patvirtina ne tik studijų dalykų ar atskirų temų, plètojančiu komunikacinę kompetencija, išskyrimas, bet ir ju turinio analizè.

V. Chreptavičienè (1998 b) teigia, kad formuojant komunikacinę kompetenciją yra galimos dvi 
didaktinès strategijos: klasikinė ir pagrịsta veikla. Universitetiniu studiju praktikoje šios kompetencijos ugdymui, autorès nuomone, tikslingiausia taikyti klasikini ugdymo modelį. Jis prasideda teorinėmis žiniomis apie veikimo būda, o pratybose, taikant efektyvius mokymo metodus, vyks paties veikimo būdo mokymasis ir tobulinimas. Kad komunikaciniu mokejjimų ugdymas, orientuotas i praktika, yra nepakankamas, teigia ir B. Grebliauskienè (1999). Autorè nurodo, kad tam reikalingos nuoseklios, išsamios ir pakankamai universalios žinios, kurios vẻliau leis kūrybiškai jas panaudoti praktinejje veikloje. Studijų dalyku temų analizé atskleidè, kad didžiausias dèmesys komunikacinès kompetencijos ugdymo metu skiriamas pratyboms. Nors pratybų metodas ir nurodomas kaip ypač svarbus ugdant komunikacinius mokejjimus, visgi jo pagrindas yra igytų teorinių žinių taikymas. Jei ugdymo procese apsiribojama praktiniu bloku, tikètina, kad bus ugdomi statiški, nelankstūs ir priimtini tik tam tikromis sąlygomis komunikaciniai mokejjimai. Taigi jų pagrindu bus sunku pasirengti sąmoningai komunikacinei kompetencijai, kuri yra būtina kiekvienam studijas baigusiam kūno kultūros mokytojui.
Ši analizè patvirtina K. Wendt ir kt. (1983) teigini, kad studijų programos dažniausiai sudaromos universitetu ,intelektų“, todèl jose daug mažiau dèmesio skiriama tam, ko iš tikrujų reikès būsimam mokytojui praktikoje (Wong, Louie, 2002). Taip pat studiju programos vis dar nèra grindžiamos būsimujų profesijų kompetencijomis, nors universitetiniu studijų metu tai yra būtina.

\section{IŠVADOS}

1. Norint kūno kultūros mokytojui paveikiai bendrauti, yra būtina komunikacinè kompetencija, kuri turi būti atitinkamai ugdoma studijų metu aukštojoje mokykloje.

2. LKKA studiju programos turinyje didžiausias dėmesys skiriamas lingvistinei subkompetencijai, visos kitos ugdomos fragmentiškai ir iš dalies.

3. Jei nėra sukurta teorinè-didaktinè koncepcija, sistemingai aprašanti ir numatanti komunikacinę kompetenciją lemiančius gebėjimus, galima teigti, kad kūno kultūros mokytojų rengimo procesee komunikacinè kompetencija yra formuojama ir plètojama nepakankamai.

\section{LITERATŪRA}

Almeida, E. P. (2002). A discourse analysis of student perceptions of their communication competence. Paper presented at the annual meeting of the Southern States Communication Association. April 3-7. Winston-Salem, NC.

Aukštikalnytė, D. (2000). Būsimu muzikos mokytoju rengimas pedagoginiam bendravimui: daktaro disertacija. Vilnius.

Beighle, A., Pangrozi, R. P. (2001). The seven habits of highly effective physical education teachers. Teaching Elementary Physical Education, 13 (4), 6-9.

Bitinas, B. (2004). Hodegetika. Auklejimo teorija ir technologijos. Vilnius: Kronta.

Brooks, M. (1985). The teacher's communicative competence: The first day of school. Theory Into Practice, XXIV (1), 63-70.

Cecevičiūtè, I. (2003). Studentu komunikacinès kompetencijos ugdymas tikslinèje edukacineje aplinkoje: daktaro disertacija. Kaunas.

Chreptavičienè, V. (1998 a). Dalykinès komunikacijos raštu mokejjimu samprata, lygiai. P. Jucevičienè ir kt. Edukologijos idejos Lietuvos švietimo sistemos modernizavimui (pp. 136-152). Kaunas: Technologija.

Chreptavičienė, V. (1998b). Dalykinės komunikacijos raštu mokejjimų ugdymo sistema universitetinèse studijose. P. Jucevičienè ir kt. Edukologijos idejos Lietuvos švietimo sistemos modernizavimui (pp. 353-374). Kaunas: Technologija.
Fiske, J. (1998). Lvadas i komunikacijos studijas. Vilnius: Baltos lankos.

Grebliauskienė, B. (1999). ENKMUS: Etapinè nerašytiniu komunikaciniu mokejjimu sistema. Metodinè priemone pedagogui. Vilnius: Žara.

Grebliauskienė, B. (1998). Nerašytinių komunikacinių mokèjimų ugdymo sistema. P. Jucevičienė ir kt. Edukologijos idejos Lietuvos švietimo sistemos modernizavimui (pp. 335-353). Kaunas: Technologija.

Grebliauskienė, B., Večkienė N. (2004). Komunikacine kompetencija. Komunikabilumo ugdymas. Vilnius: Žara.

Irvin, M. E. (1990). Subject matter assessment of prospective physical education teachers. Report of the California State University Workgroup, May 10-12, 1990. California State Univ. and Colleges, Long Beach.

Jakavičius, V. (1998). Žmogaus ugdymas: ¿̇vadas i edukologijos studijas. Klaipèda: Klaipèdos universiteto leidykla.

Jovaiša, L. (1993). Pedagogikos terminai. Kaunas: Šviesa.

Kardelienė, L., Gudzinevičiūtė, O. L., Mykolaitienė, L. (2004). Būsimujų kūno kultūros specialistų ir sporto pedagogu kalba kaip kokybiškos komunikacijos kodas. Pedagogika, 73, 49-53.

Kardelis, K. (2002). Moksliniu tyrimu metodologija ir metodai: vadovelis. Kaunas: Judex.

Lietuviu kalbos ugdymo bendrojo lavinimo mokyklos 
strategija 2004-2009 m. Projektas 2003-12-30. Prieiga per internetą: www.smm.lt

LKKA pagrindiniu (bakalauro) studiju programa „Kūno kultūra“. (2004).

Malinauskas, R. (1999). Socialinis pedagogu rengimas: daktaro disertacija. Kaunas.

Millrood, R. (2001). Modules in English Language Teaching Methodology. Tambov: TGU.

Miškinis, K. (2000). Kūno kultūros ir sporto specialistu rengimo tobulinimas. Kaunas: LKKA.

Nauckūnaitè, Z. (2000). Būsimujų mokytojų komunikacinès kompetencijos ugdymas universitetinése studijose. Švietimo reforma ir mokytoju rengimas: VII tarptautine moksline konferencija. Mokslo darbai. (pp. 170-177). Vilnius: VPU.

Nedwidek, R. A., Rubinstein, D. J. (1970). Voice and communication in student teaching. Education, 90 (4), 293-297.
Podgorecki, J. (2005). Socialine komunikacija mokytojams.Vilnius: VPU leidykla.

Poškienè, A. (2004). Kas yra diskursas. Kaunas: Technologija.

Rogers, D. L., Noblit, G. W., Ferrell, P. (1990). Action research as an agent for developing teachers' communicative competence. Theory Into Practice, XXIX (3), 179-184.

Večkienė, N., Grebliauskienė, B., Sokolovienė, D., Chreptavičienè, V. (1998). Komunikacija ir bendravimas: sampratų santykio problema. P. Jucevičienè ir kt. Edukologijos idejos Lietuvos švietimo sistemos modernizavimui (pp. 113-135). Kaunas: Technologija.

Wong, A., Louie, L. (2002). What professional educators can learn from practising physical education teachers? Physical Educator, 59 (2), 90-104.

Лобанов, А. А. (2002). Основы профессионально-педагогического общения. Москва: ACADEMA.

\title{
THE DEVELOPMENT OF COMMUNICATION COMPETENCE IN THE PROCESS OF PHYSICAL EDUCATION TEACHER'S TRAINING
}

\author{
Vilija Fominienè \\ Lithuanian Academy of Physical Education, Kaunas, Lithuania
}

\begin{abstract}
The article analyses the conception of communication competence, the importance of a physical education teacher's practical activities and possibilities in a teacher's education. The objective of the research work was to establish if the future physical education teachers' sub-competencies of communication competence are trained in the study process, depending on a study program. The LAPE's study program "Physical Education" and the question if study subject-matter (subject-matter annotation and programs) gives future physical education teachers knowledge, skills and abilities in communication competence development were analysed.

The results of the analysis show that focal attention in future physical education teachers' training is paid to the sub-competence of linguistics and little to the others.

In summary we can draw the conclusion that there is no theoretical-didactic conception, which systematically describes and supposes abilities, determinant to that competence. It means that communication competence in future physical education teachers is not enough developing.
\end{abstract}

Keywords: communication, communication competence, a physical education teacher’s training.

Gauta 2005 m. balandžio 20 d.

Received on April 20, 2005

Priimta 2006 m. vasario $20 \mathrm{~d}$.

Accepted on February 20, 2006
Vilija Fominienè

Lietuvos kūno kultūros akademija

(Lithuania Academy of Physical Education)

Sporto g. 6, LT-44221 Kaunas

Lietuva (Lithuania)

Tel +370 37302637

E-mail v.fominiene@lkka.lt 